\title{
Trends in intensive care unit admissions of COPD patients from 2003 to 2013 in Taiwan
}

This article was published in the following Dove Press journal: International Journal of COPD

\section{Kuang-Ming Liao' \\ Yi-Chen Chen ${ }^{2}$ \\ Kuo-Chen Cheng ${ }^{3}$ \\ Jhi-Joung Wang ${ }^{2}$ \\ Chung-Han $\mathrm{Ho}^{2,4}$}

'Department of Internal Medicine, Chi Mei Medical Center, Chiali, Taiwan; ${ }^{2}$ Department of Medical Research, Chi Mei Medical Center, Tainan, Taiwan; ${ }^{3}$ Department of Internal Medicine, Chi Mei Medical Center, Tainan, Taiwan; ${ }^{4}$ Department of Hospital and Health Care Administration, Chia Nan University of Pharmacy and Science, Tainan, Taiwan
Correspondence: Chung-Han Ho Department of Medical Research, Chi Mei Medical Center, No 90I, Zhonghua Road, Yongkang District, Tainan 710, Taiwan Tel +886 628 I 28I Ix52653 Email ho.c.hank@gmail.com
Objective: The objective of this study was to investigate the trends in COPD patients admitted to the intensive care unit (ICU) in Taiwan from 2003 to 2013.

Patients and methods: A retrospective study was conducted to analyze the available data in the National Health Insurance Research Database compiled by the Taiwan Department of Health. We selected patients admitted to the ICU nationwide from 2003 to 2013. Patients older than 40 years with a diagnosis of COPD were enrolled. The ICU admission date was used as the index date. Baseline comorbidities existing before the index date were identified. The comorbidities of interest included diabetes, hypertension, diabetes mellitus, coronary artery disease, stroke, dyslipidemia, cancer, and end-stage renal disease.

Results: The number of COPD patients in the ICU increased from 12,384 in 2003 to 13,308 in $2013(P<0.0001)$. The mean age of patients and SD was $76.66 \pm 9.48$ and $78.32 \pm 10.59$ in 2003 and 2013, respectively. The percentage of COPD patients aged $\geq 70$ years in the ICU decreased markedly. COPD patients per 10,000 ICU patients decreased for both males and females. The length of ICU stays, and in-hospital mortality increased from 21.58 to 23.14 days and $14.97 \%$ to $30.98 \%$ from 2003 to 2013 , respectively.

Conclusion: The number of COPD patients admitted to the ICU in Taiwan increased over the 11-year study period. Increased mean patient age, length of ICU stays, hospital mortality, and comorbidities were observed. The use of a nationwide population-based database allowed for a sufficient sample size, generalizability, and statistical power to analyze COPD patients admitted to the ICU in Taiwan.

Keywords: COPD, intensive care unit, trend

\section{Introduction}

COPD is a progressive obstructive lung disease and a major cause of mortality and morbidity. COPD is characterized by airway obstruction that is not fully reversible and systemic inflammation. COPD is currently the fourth leading cause of death in the world. ${ }^{1}$ COPD patients have high morbidity and frequently experience acute exacerbations requiring hospitalization. Hospitalizations, particularly intensive care unit (ICU) admissions, have imposed substantial and increasing economic and social costs. ${ }^{1}$ Prevalence, morbidity, and mortality of COPD vary among different countries and races, and variations are also observed across different groups within countries. Hospitalization is one of the major economic burdens of COPD. A previous study in the USA showed that COPD was responsible for 1.5 million emergency department visits, 726,000 hospitalizations, and 119,000 deaths in $2000 .^{2}$ Most studies have focused on hospitalizations for acute COPD exacerbations to assess the trends in patient characteristics, mortality with respect to variables such as length of stay and complications, and the economic burden of COPD. Fuhrman et $\mathrm{al}^{3}$ reported that hospital admissions 
for acute COPD exacerbations increased in France from 1998 to 2007, particularly among women, although in-hospital mortality decreased. de Miguel-Díez et $\mathrm{al}^{4}$ reported that hospitalizations for acute COPD exacerbations decreased in Spain from 2006 to 2010 and were associated with decreased in-hospital mortality and increased patient comorbidity without prolonged hospital stays. Molinari et $\mathrm{al}^{5}$ used administrative data and found that hospitalizations and deaths due to severe COPD exacerbations increased from 2010 to 2012 in France. Scant data on ICU admissions of COPD patients exist on a national scale. The current study was designed to perform an evaluation of the trends in ICU admissions of COPD patients. The aim of this study was to assess the trends regarding ICU admissions, comorbid diagnoses, in-hospital mortality, and length of stay of COPD patients admitted to the ICU from 2003 to 2013 in Taiwan.

\section{Patients and methods Database}

Data obtained from the Taiwan National Health Insurance Research Database (NHIRD) from January 1, 2003, to December 31, 2013, were used for the analysis. The NHIRD is a nationwide database that includes all inpatient and outpatient medical benefit claims for the Taiwanese population. Taiwan's National Health Insurance currently enrolls $>23$ million legal residents, comprising $299.7 \%$ of Taiwan's population. The International Classification of Diseases, Ninth Revision, Clinical Modification (ICD-9-CM) diagnostic and procedure codes were used for this nationwide health insurance system.

This study was approved by the ethics committee of the Institutional Review Board of Chi Mei Medical Center on the basis that the patients' private or individual data will not be made public due to the unique codes used in the database. The study was approved by the institutional review board (IRB) of the Chi Mei Medical Center (IRB no: 10411-E01).

\section{Study sample}

COPD patients older than 40 years with all-cause ICU admissions between January 1, 2003, and December 31, 2013, were enrolled in this study. The identification of the diagnosis of COPD was based on the ICD-9-CM diagnosis codes 490-492 and 496. Age, gender, and comorbidity data were collected. Comorbidities were defined as conditions present within the year prior to the ICU admission date pertaining to the following ICD-9-CM codes: 1) diabetes (ICD-9-CM: 250), 2) hypertension (ICD-9-CM: 401-405), 3 ) coronary artery disease (ICD-9-CM: 410-414), 4) stroke
(ICD-9-CM: 430-438), 5) dyslipidemia (ICD-9-CM: 272), 6) cancer (ICD-9-CM: 140-208), and 7) end-stage renal disease (ESRD; ICD-9-CM: 585). Hospital mortality was based on the death records from the inpatient claims database.

Laboratory information was not included in the claims database; therefore, only the admission date, discharge date, patient profile, and ICD-9 diagnosis codes were available; notably, the correct coding for each COPD patient could not be confirmed due to the lack of spirometry values in the claims database. However, according to the NHI program policy, peer reviews from independent physicians serve as an auditing system for these claims. If the diagnosis or claim influenced the treatment used, the claim would be invoked. As a result, we relied on this internal validation system for the authenticity of our data.

\section{Statistical analyses}

Data analyses were performed using SAS 9.4 for Windows (SAS Institute Inc., Cary, NC, USA). Categorical variables, such as age group, gender, comorbidities, and in-hospital mortality, were presented as frequencies and percentages. Continuous variables, such as age and length of ICU stay, were reported as mean with SD. The trend tests for age, gender, comorbidities, and mortality were analyzed using linear regression for the years 2003-2013. Significance was set at $P<0.05$ (two sided).

\section{Results}

During the 11-year period, a total of 99,924 COPD patients admitted to the ICU were recorded. The mean patient age was 77.67 years with an SD of 10.03. Most patients were older than 70 years, who accounted for $82 \%$ of the subjects, and males predominated $(78.3 \%)$. The three most common comorbidities were hypertension, coronary artery disease, and diabetes (Table 1).

In 2003, 12,384 COPD patients (8.53\% of all ICU admissions) were identified among the national cohort of ICU admissions from Longitudinal Health Insurance Database. The number of COPD patients in the ICU increased from 12,384 in 2003 to 13,308 in 2013. The mean age increased from 76.66 years in 2003 to 78.32 years in 2013. After stratification, the number of patients aged 50-59 years increased significantly from $498(4.02 \%)$ to $675(5.07 \% ; P<0.0001)$, with no increase observed in the other age groups. Patients older than 70 years comprised $>81 \%$ of COPD patients in the ICU. A male predominance was observed with a slight increase in the proportion of males from $76.61 \%$ in 2003 to $78.53 \%$ in $2013(P<0.0001)$. Hypertension accounted for 
Table I Characteristics of COPD patients in the ICU from 2003 to 2013

\begin{tabular}{ll}
\hline Characteristics & $\begin{array}{l}\text { COPD patients } \\
(\mathbf{N}=\mathbf{9 9 , 9 2 4 )}\end{array}$ \\
\hline Age, mean (SD) & $77.67(10.03)$ \\
40-49 years & $1,509(1.51)$ \\
$50-59$ years & $4,393(4.40)$ \\
$60-69$ years & $11,863(11.87)$ \\
$\geq 70$ years & $82,159(82.22)$ \\
Gender, $n(\%)$ & \\
Female & $21,688(21.70)$ \\
Male & $78,236(78.30)$ \\
Comorbidity, $n$ (\%) & \\
Diabetes & $21,600(21.62)$ \\
Hypertension & $39,237(39.27)$ \\
Coronary artery disease & $23,506(23.52)$ \\
Stroke & $18,179(18.19)$ \\
Dyslipidemia & $3,114(3.12)$ \\
Cancer & $11,699(11.71)$ \\
ESRD & $3,467(3.47)$ \\
\hline
\end{tabular}

Abbreviations: ESRD, end-stage renal disease; ICU, intensive care unit.

the highest patient comorbidity percentage, ie, $31.77 \%$ in 2003 to $45.36 \%$ in 2013 , followed by diabetes and coronary artery disease. In contrast, the proportions of other comorbidities including coronary artery disease, stroke, and ESRD slightly declined over time. The length of ICU stays (mean: 21.58-23.14, $P<0.0001)$ and in-hospital mortality $(14.97 \%$ $30.98 \%, P=0.0007$ ) increased from 2003 to 2013 (Table 2).

The trends in COPD patients per 10,000 ICU patients are summarized in Table 3. The number of COPD patients in the ICU aged 50-59 years gradually decreased from 238.7 per 10,000 ICU patients in 2003 to 206.4 per 10,000 ICU patients in $2013(P=0.0054)$. A decreasing trend in annual cases was observed for both genders for patients aged 50-59, 60-69, and older than 70 years. No significant difference between 2003 and 2013 was observed for the group aged $40-49$ years. Figure 1 shows the trends in COPD patients per 10,000 ICU patients by age group. Figure 2 shows the trends in COPD patients per 10,000 ICU patients by gender.

\section{Discussion}

To the best of our knowledge, this is the first study to use a national database to investigate the trends in COPD patients admitted to the ICU. Our study analyzed the number of COPD patients in the ICU, their comorbidities, length of ICU stay, and in-hospital mortality during an 11-year period in Taiwan. Markedly increased trends were observed for case numbers, length of ICU stay, and in-hospital mortality from 2003 to 2013. The comorbidities of diabetes and hypertension among COPD patients also increased.
Hospitalization is one of the major factors contributing to the socioeconomic burden of COPD. ${ }^{6}$ Approximately 10 million adults, in the USA, are diagnosed with COPD, and COPD was responsible for 726,000 hospitalizations and 119,000 deaths in 2000. The COPD death rate increased from $20.1 / 100,000$ in 1980 to $56.7 / 100,000$ in 2000 for women and from 73.0/100,000 in 1980 to 82.6/100,000 in 2000 for men. Another significant trend was observed in the proportion of the population aged $<55$ years, which decreased from 1971-1975 to $1988-1994 .^{7}$ In our study, we found that the proportion of COPD patients aged 40-49 years in Taiwan did not change significantly from 2003 to 2013 . However, the proportion of COPD patients in the other age groups, including 50-59, 60-69, and $\geq 70$ years, significantly increased during this period. The number of COPD patients admitted to the ICU increased for patients older than 50 years. Approaches to reduce the risk of developing COPD, the control of disease severity and hospitalization avoidance, including the control of risk factors such as smoking and exposure to air pollution and occupational dust, remain important issues.

In Brazil, Benseñor et $\mathrm{al}^{8}$ found decreased COPD hospitalization rates but increased in-hospital mortality for both genders from 1996 to 2008 and that COPD remained a leading cause of mortality. In our study, we found that the in-hospital mortality and length of ICU stay increased from 2003 to 2013. One explanation for this finding may be that the Taiwan population aged progressively over the study period. Japan has the oldest citizenry in the world with $27 \%$ of its population aged 65 years or older in 2016. Other countries such as Italy, Germany, Portugal, and Finland also have high percentages of aged citizens with those 65 years of age or older comprising $>20 \%$ of their populations. ${ }^{9}$

This trend may also apply to other countries. Aging occurs in other parts of the world and is associated with an increasing prevalence of chronic diseases and complex medical conditions. Such shifts in demographic characteristics will have a great impact on the future health care system and medical expenditures. Our study also demonstrated that some chronic diseases such as diabetes, hypertension, and coronary artery disease were increased in COPD patients admitted to the ICU. Cheng et $\mathrm{al}^{10}$ used the NHIRD to analyze ICU characteristics between March 2004 and February 2009 and reported that the average ICU stay was $6.5 \pm 0.5$ days and that the overall ICU mortality rate was $20.2 \%$. In our study, we found that COPD patients admitted to the ICU had higher mortality and longer ICU stays than the general population. Thus, COPD appears to be a poor prognostic factor in the ICU. 
Table 2 Trends of baseline characteristics among COPD patients in the ICU

\begin{tabular}{|c|c|c|c|c|c|c|c|c|c|c|c|c|}
\hline \multirow[t]{2}{*}{ Characteristics } & \multicolumn{11}{|l|}{ Years } & \multirow[t]{2}{*}{$P$-value } \\
\hline & 2003 & 2004 & 2005 & 2006 & 2007 & 2008 & 2009 & 2010 & 2011 & 2012 & 2013 & \\
\hline No of patients, n (\%) & $\begin{array}{l}12,384 \\
(8.53)\end{array}$ & $\begin{array}{l}14,334 \\
(8.97)\end{array}$ & $\begin{array}{l}15,224 \\
(9.12)\end{array}$ & $\begin{array}{l}14,706 \\
(8.54)\end{array}$ & $\begin{array}{l}14,862 \\
(8.4 I)\end{array}$ & $\begin{array}{l}14,450 \\
(7.98)\end{array}$ & $\begin{array}{l}|4,39| \\
(7.70)\end{array}$ & $\begin{array}{l}15,099 \\
(7.84)\end{array}$ & $\begin{array}{l}15,062 \\
(7.72)\end{array}$ & $\begin{array}{l}14,848 \\
(7.57)\end{array}$ & $\begin{array}{l}13,308 \\
(6.93)\end{array}$ & $<0.0001$ \\
\hline Age mean (SD) & $\begin{array}{l}76.66 \\
(9.48)\end{array}$ & $\begin{array}{l}76.93 \\
(9.53)\end{array}$ & $\begin{array}{l}77.28 \\
(9.72)\end{array}$ & $\begin{array}{l}77.55 \\
(9.65)\end{array}$ & $\begin{array}{l}78.12 \\
(9.57)\end{array}$ & $\begin{array}{l}78.23 \\
(9.81)\end{array}$ & $\begin{array}{l}78.19 \\
(10.21)\end{array}$ & $\begin{array}{l}78.47 \\
(10.14)\end{array}$ & $\begin{array}{l}78.50 \\
(10.35)\end{array}$ & $\begin{array}{l}78.67 \\
(10.45)\end{array}$ & $\begin{array}{l}78.32 \\
(10.59)\end{array}$ & \\
\hline $40-49$ years & $\begin{array}{l}176 \\
(1.42)\end{array}$ & $\begin{array}{l}288 \\
(I .45)\end{array}$ & $\begin{array}{l}220 \\
(1.45)\end{array}$ & $\begin{array}{l}188 \\
(1.28)\end{array}$ & $\begin{array}{l}177 \\
(1.19)\end{array}$ & $\begin{array}{l}183 \\
(1.27)\end{array}$ & $\begin{array}{l}209 \\
(1.45)\end{array}$ & $\begin{array}{l}210 \\
(1.39)\end{array}$ & $\begin{array}{l}209 \\
(1.39)\end{array}$ & $\begin{array}{l}199 \\
(1.34)\end{array}$ & $\begin{array}{l}176 \\
(1.32)\end{array}$ & 0.5104 \\
\hline $50-59$ years & $\begin{array}{l}498 \\
(4.02)\end{array}$ & $\begin{array}{l}551 \\
(3.84)\end{array}$ & $\begin{array}{l}633 \\
(4.16)\end{array}$ & $\begin{array}{l}631 \\
(4.29)\end{array}$ & $\begin{array}{l}588 \\
(3.96)\end{array}$ & $\begin{array}{l}619 \\
(4.28)\end{array}$ & $\begin{array}{l}700 \\
(4.86)\end{array}$ & $\begin{array}{l}685 \\
(4.54)\end{array}$ & $\begin{array}{l}688 \\
(4.57)\end{array}$ & $\begin{array}{l}694 \\
(4.67)\end{array}$ & $\begin{array}{l}675 \\
(5.07)\end{array}$ & 0.0005 \\
\hline 60-69 years & $\begin{array}{l}1,627 \\
(13.14)\end{array}$ & $\begin{array}{l}1,835 \\
(12.80)\end{array}$ & $\begin{array}{l}\mathrm{I}, 883 \\
(12.37)\end{array}$ & $\begin{array}{l}1,733 \\
\text { (II.78) }\end{array}$ & $\begin{array}{l}1,572 \\
(10.58)\end{array}$ & $\begin{array}{l}1,543 \\
(10.68)\end{array}$ & $\begin{array}{l}1,609 \\
(11.18)\end{array}$ & $\begin{array}{l}1,612 \\
(10.68)\end{array}$ & $\begin{array}{l}\text { I,71। } \\
(I I .36)\end{array}$ & $\begin{array}{l}\text { I,674 } \\
\text { (II.27) }\end{array}$ & $\begin{array}{l}1,645 \\
(12.36)\end{array}$ & 0.1242 \\
\hline$\geq 70$ years & $\begin{array}{l}10,083 \\
(81.42)\end{array}$ & $\begin{array}{l}11,740 \\
(81.90)\end{array}$ & $\begin{array}{l}12,488 \\
(82.03)\end{array}$ & $\begin{array}{l}12,154 \\
(82.65)\end{array}$ & $\begin{array}{l}12,525 \\
(84.28)\end{array}$ & $\begin{array}{l}12,105 \\
(83.77)\end{array}$ & $\begin{array}{l}I I, 873 \\
(82.50)\end{array}$ & $\begin{array}{l}12,592 \\
(83.40)\end{array}$ & $\begin{array}{l}12,454 \\
(82.68)\end{array}$ & $\begin{array}{l}|2,28| \\
(82.7 \mid)\end{array}$ & $\begin{array}{l}10,812 \\
(81.24)\end{array}$ & 0.7076 \\
\hline Gender, n (\%) & & & & & & & & & & & & \\
\hline Male & $\begin{array}{l}9,487 \\
(76.61)\end{array}$ & $\begin{array}{l}10,965 \\
(76.50)\end{array}$ & $\begin{array}{l}11,558 \\
(75.92)\end{array}$ & $\begin{array}{l}|I, 32| \\
(76.98)\end{array}$ & $\begin{array}{l}11,440 \\
(76.97)\end{array}$ & $\begin{array}{l}11,213 \\
(77.60)\end{array}$ & $\begin{array}{l}11,130 \\
(77.34)\end{array}$ & $\begin{array}{l}11,654 \\
(77.18)\end{array}$ & $\begin{array}{l}11,742 \\
(77.96)\end{array}$ & $\begin{array}{l}11,599 \\
(78.12)\end{array}$ & $\begin{array}{l}|8,45| \\
(78.53)\end{array}$ & 0.0002 \\
\hline Comorbidity, n (\%) & & & & & & & & & & & & \\
\hline Diabetes & $\begin{array}{l}2,624 \\
(21.19)\end{array}$ & $\begin{array}{l}3,340 \\
(23.30)\end{array}$ & $\begin{array}{l}3,656 \\
(24.01)\end{array}$ & $\begin{array}{l}3,629 \\
(24.68)\end{array}$ & $\begin{array}{l}3,723 \\
(25.05)\end{array}$ & $\begin{array}{l}3,688 \\
(25.52)\end{array}$ & $\begin{array}{l}3,627 \\
(25.20)\end{array}$ & $\begin{array}{l}3,965 \\
(26.26)\end{array}$ & $\begin{array}{l}3,962 \\
(26.30)\end{array}$ & $\begin{array}{l}3,969 \\
(26.73)\end{array}$ & $\begin{array}{l}3,508 \\
(26.36)\end{array}$ & $<0.000 \mathrm{I}$ \\
\hline Hypertension & $\begin{array}{l}3,934 \\
(31.77)\end{array}$ & $\begin{array}{l}5,754 \\
(40.14)\end{array}$ & $\begin{array}{l}6,338 \\
(41.63)\end{array}$ & $\begin{array}{l}6,241 \\
(42.44)\end{array}$ & $\begin{array}{l}6,477 \\
(43.58)\end{array}$ & $\begin{array}{l}6,286 \\
(43.50)\end{array}$ & $\begin{array}{l}6,408 \\
(44.53)\end{array}$ & $\begin{array}{l}6,740 \\
(44.64)\end{array}$ & $\begin{array}{l}6,724 \\
(44.64)\end{array}$ & $\begin{array}{l}6,606 \\
(44.49)\end{array}$ & $\begin{array}{l}6,036 \\
(45.36)\end{array}$ & 0.0047 \\
\hline $\begin{array}{l}\text { Coronary artery } \\
\text { disease }\end{array}$ & $\begin{array}{l}3,037 \\
(24.52)\end{array}$ & $\begin{array}{l}3,966 \\
(27.67)\end{array}$ & $\begin{array}{l}4,197 \\
(27.57)\end{array}$ & $\begin{array}{l}4,002 \\
(27.21)\end{array}$ & $\begin{array}{l}3,877 \\
(26.09)\end{array}$ & $\begin{array}{l}3,765 \\
(26.06)\end{array}$ & $\begin{array}{l}3,501 \\
(24.33)\end{array}$ & $\begin{array}{l}3,67 I \\
(24.3 I)\end{array}$ & $\begin{array}{l}3,435 \\
(22.81)\end{array}$ & $\begin{array}{l}3,301 \\
(22.23)\end{array}$ & $\begin{array}{l}2,984 \\
(22.42)\end{array}$ & 0.0029 \\
\hline Stroke & $\begin{array}{l}2,214 \\
(17.88)\end{array}$ & $\begin{array}{l}3,249 \\
(22.67)\end{array}$ & $\begin{array}{l}3,621 \\
(23.78)\end{array}$ & $\begin{array}{l}3,691 \\
(25.10)\end{array}$ & $\begin{array}{l}3,666 \\
(24.67)\end{array}$ & $\begin{array}{l}3,336 \\
(23.09)\end{array}$ & $\begin{array}{l}3,304 \\
(22.96)\end{array}$ & $\begin{array}{l}3,265 \\
(21.62)\end{array}$ & $\begin{array}{l}3,134 \\
(20.8 I)\end{array}$ & $\begin{array}{l}3,091 \\
(20.82)\end{array}$ & $\begin{array}{l}2,556 \\
(19.21)\end{array}$ & 0.4644 \\
\hline Dyslipidemia & $\begin{array}{l}276 \\
(2.23)\end{array}$ & $\begin{array}{l}426 \\
(2.97)\end{array}$ & $\begin{array}{l}487 \\
(3.20)\end{array}$ & $\begin{array}{l}424 \\
(2.88)\end{array}$ & $\begin{array}{l}467 \\
(3.14)\end{array}$ & $\begin{array}{l}443 \\
(3.07)\end{array}$ & $\begin{array}{l}462 \\
(3.21)\end{array}$ & $\begin{array}{l}478 \\
(3.17)\end{array}$ & $\begin{array}{l}517 \\
(3.43)\end{array}$ & $\begin{array}{l}513 \\
(3.46)\end{array}$ & $\begin{array}{l}459 \\
(3.45)\end{array}$ & 0.0023 \\
\hline Cancer & $\begin{array}{l}1,135 \\
(9.17)\end{array}$ & $\begin{array}{l}1,467 \\
(10.23)\end{array}$ & $\begin{array}{l}1,627 \\
(10.69)\end{array}$ & $\begin{array}{l}1,613 \\
(10.97)\end{array}$ & $\begin{array}{l}1,669 \\
(11.23)\end{array}$ & $\begin{array}{l}1,563 \\
(10.82)\end{array}$ & $\begin{array}{l}1,612 \\
(11.20)\end{array}$ & $\begin{array}{l}1,715 \\
(11.36)\end{array}$ & $\begin{array}{l}1,654 \\
(10.98)\end{array}$ & $\begin{array}{l}1,689 \\
(I 1.38)\end{array}$ & $\begin{array}{l}1,534 \\
(11.53)\end{array}$ & 0.0027 \\
\hline ESRD & $\begin{array}{l}632 \\
(5.10)\end{array}$ & $\begin{array}{l}749 \\
(5.23)\end{array}$ & $\begin{array}{l}703 \\
(4.62)\end{array}$ & $\begin{array}{l}665 \\
(4.52)\end{array}$ & $\begin{array}{l}624 \\
(4.20)\end{array}$ & $\begin{array}{l}546 \\
(3.78)\end{array}$ & $\begin{array}{l}487 \\
(3.38)\end{array}$ & $\begin{array}{l}541 \\
(3.58)\end{array}$ & $\begin{array}{l}493 \\
(3.27)\end{array}$ & $\begin{array}{l}540 \\
(3.64)\end{array}$ & $\begin{array}{l}463 \\
(3.48)\end{array}$ & $<0.000$ I \\
\hline $\begin{array}{l}\text { Length of ICU stay } \\
\text { (days), mean (SD) }\end{array}$ & $\begin{array}{l}21.58 \\
(29.08)\end{array}$ & $\begin{array}{l}25.28 \\
(32.73)\end{array}$ & $\begin{array}{l}25.50 \\
(34.08)\end{array}$ & $\begin{array}{l}26.12 \\
(34.34)\end{array}$ & $\begin{array}{l}27.30 \\
(37.20)\end{array}$ & $\begin{array}{l}27.09 \\
(37.01)\end{array}$ & $\begin{array}{l}26.25 \\
(37.47)\end{array}$ & $\begin{array}{l}27.14 \\
(39.66)\end{array}$ & $\begin{array}{l}25.68 \\
(37.27)\end{array}$ & $\begin{array}{l}25.62 \\
(37.48)\end{array}$ & $\begin{array}{l}23.14 \\
(32.00)\end{array}$ & $<0.0001$ \\
\hline $\begin{array}{l}\text { In-hospital mortality, } \\
\text { n (\%) }\end{array}$ & $\begin{array}{l}1,854 \\
(14.97)\end{array}$ & $\begin{array}{l}2,122 \\
(14.80)\end{array}$ & $\begin{array}{l}2,328 \\
(15.29)\end{array}$ & $\begin{array}{l}2,449 \\
(16.65)\end{array}$ & $\begin{array}{l}4,425 \\
(29.77)\end{array}$ & $\begin{array}{l}4,416 \\
(30.56)\end{array}$ & $\begin{array}{l}4,320 \\
(30.02)\end{array}$ & $\begin{array}{l}4,705 \\
(31.16)\end{array}$ & $\begin{array}{l}4,638 \\
(30.79)\end{array}$ & $\begin{array}{l}4,477 \\
(30.15)\end{array}$ & $\begin{array}{l}4,123 \\
(30.98)\end{array}$ & 0.0007 \\
\hline
\end{tabular}

Abbreviations: ESRD, end-stage renal disease; ICU, intensive care unit.

COPD patients have a higher risk of developing cancer than patients without COPD. ${ }^{11}$ Hospice care may provide medical services, emotional support, and spiritual resources for cancer patients in terminal stages, the cancer patients have been studied using health administrative data since $2000 .{ }^{12}$ Hospice care in Taiwan is conducted by hospital- and homebased units in $87.6 \%$ and $12.4 \%$ of cases, respectively. ${ }^{13}$ In Taiwan, terminal cancer patients with a prognosis of

Table 3 Trends in COPD patients per 10,000 ICU patients

\begin{tabular}{|c|c|c|c|c|c|c|c|c|c|c|c|c|}
\hline \multirow[t]{2}{*}{ Characteristics } & \multicolumn{11}{|l|}{ Years } & \multirow[t]{2}{*}{$P$-value } \\
\hline & 2003 & 2004 & 2005 & 2006 & 2007 & 2008 & 2009 & 2010 & 2011 & 2012 & 2013 & \\
\hline $\begin{array}{l}\text { COPD patients, } \\
\text { n (\%) }\end{array}$ & $\begin{array}{l}12,384 \\
(8.53)\end{array}$ & $\begin{array}{l}14,334 \\
(8.97)\end{array}$ & $\begin{array}{l}15,224 \\
(9.12)\end{array}$ & $\begin{array}{l}14,706 \\
(8.54)\end{array}$ & $\begin{array}{l}14,862 \\
(8.4 I)\end{array}$ & $\begin{array}{l}14,450 \\
(7.98)\end{array}$ & $\begin{array}{l}|4,39| \\
(7.70)\end{array}$ & $\begin{array}{l}15,099 \\
(7.84)\end{array}$ & $\begin{array}{l}15,062 \\
(7.72)\end{array}$ & $\begin{array}{l}14,848 \\
(7.57)\end{array}$ & $\begin{array}{l}13,308 \\
(6.93)\end{array}$ & $<0.000$ \\
\hline \multicolumn{13}{|l|}{ Age } \\
\hline 40-49 years & 105.1 & 112.0 & II5.4 & 95.4 & 90.5 & 93.1 & 104.3 & 105.8 & 103.8 & 100.2 & 91.8 & 0.1989 \\
\hline 50-59 years & 238.7 & 235.2 & 245.1 & 225.9 & 203.3 & 206.1 & 219.8 & 211.4 & 210.9 & 210.8 & 206.4 & 0.0054 \\
\hline 60-69 years & 544.7 & 576.3 & 588.3 & 542.0 & 493.8 & 474.7 & 481.5 & 468.1 & 481.5 & 454.7 & 442.7 & 0.0002 \\
\hline$\geq 70$ years & $1,296.6$ & I,365.8 & $1,386.5$ & $1,313.9$ & $1,299.9$ & $\mathrm{I}, 225 . \mathrm{I}$ & $\mathrm{I}, 168.4$ & $\mathrm{I}, 188.6$ & $\mathrm{I}, 166.3$ & $\mathrm{I}, 153.0$ & $\mathrm{I}, 049.3$ & $<0.000$ I \\
\hline \multicolumn{13}{|l|}{ Gender } \\
\hline Male & I,075.I & $1,120.9$ & $1,132.7$ & $|, 07| .7$ & $1,061.2$ & $\mathrm{I}, 0 \mid 2.8$ & 974.3 & 994.8 & 983.6 & 968.6 & 888.2 & $<0.000$ \\
\hline Female & 508.3 & 543.6 & 564.6 & 509.3 & 496.9 & 460.5 & 448.6 & 456.4 & 438.6 & 425.5 & 384.0 & $<0.000$ I \\
\hline
\end{tabular}

Abbreviation: ICU, intensive care unit. 


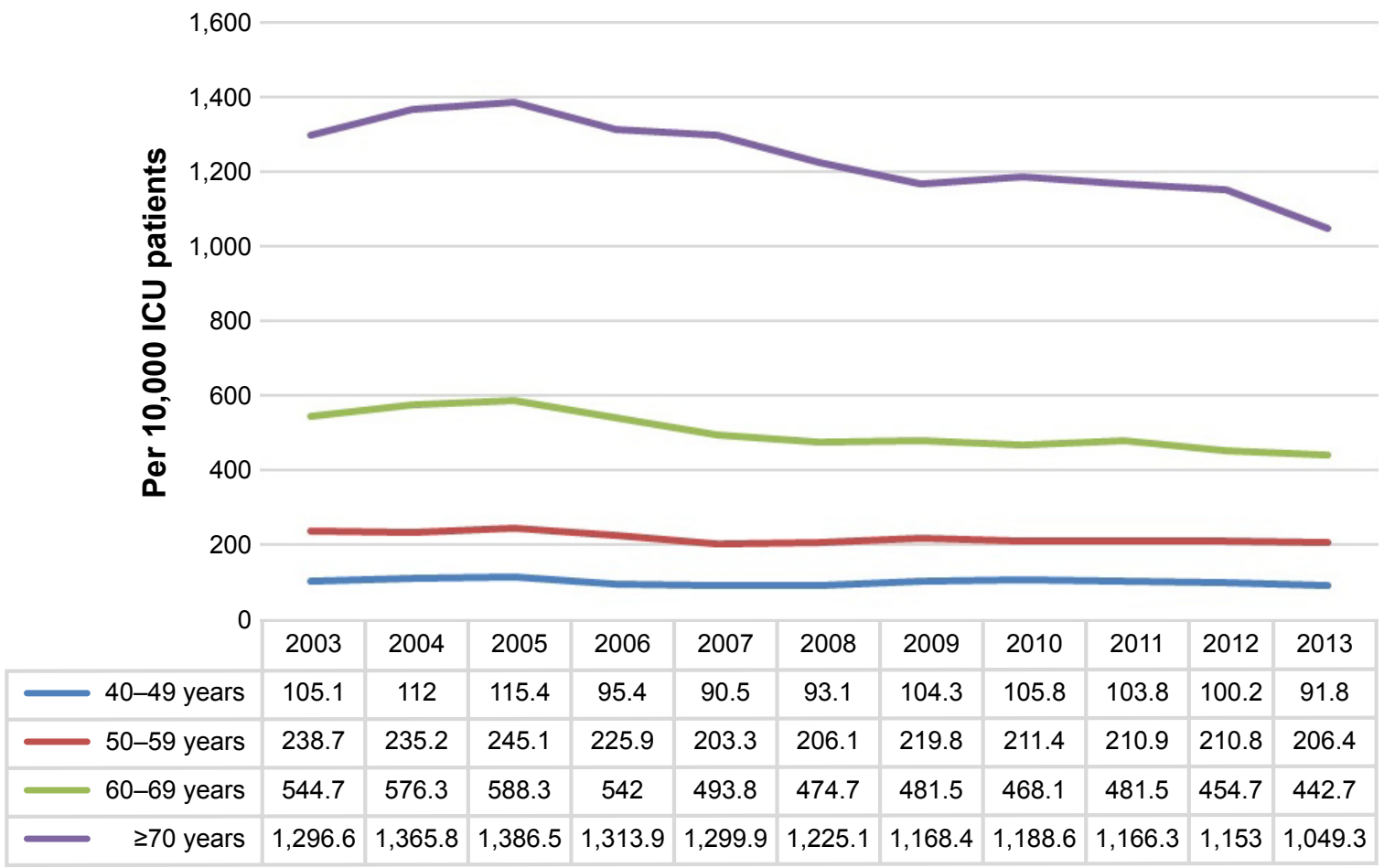

Figure I Trends in COPD patients per 10,000 ICU patients by age.

Abbreviation: ICU, intensive care unit.

$\sim 6$ months of survival or less are candidates for hospice care, and patients receiving hospice care increased from $7.34 \%$ in 2000 to $16.83 \%$ in $2006 .{ }^{14}$

However, hospice care remains underutilized because family members may not fully understand the meaning of hospice, are not prepared for the end of life, are not confident in palliative care, and may experience the emotional distress of losing a loved one. Therefore, patients with terminal illnesses are often hospitalized and receive anticancer or aggressive treatment such as intubation with mechanical

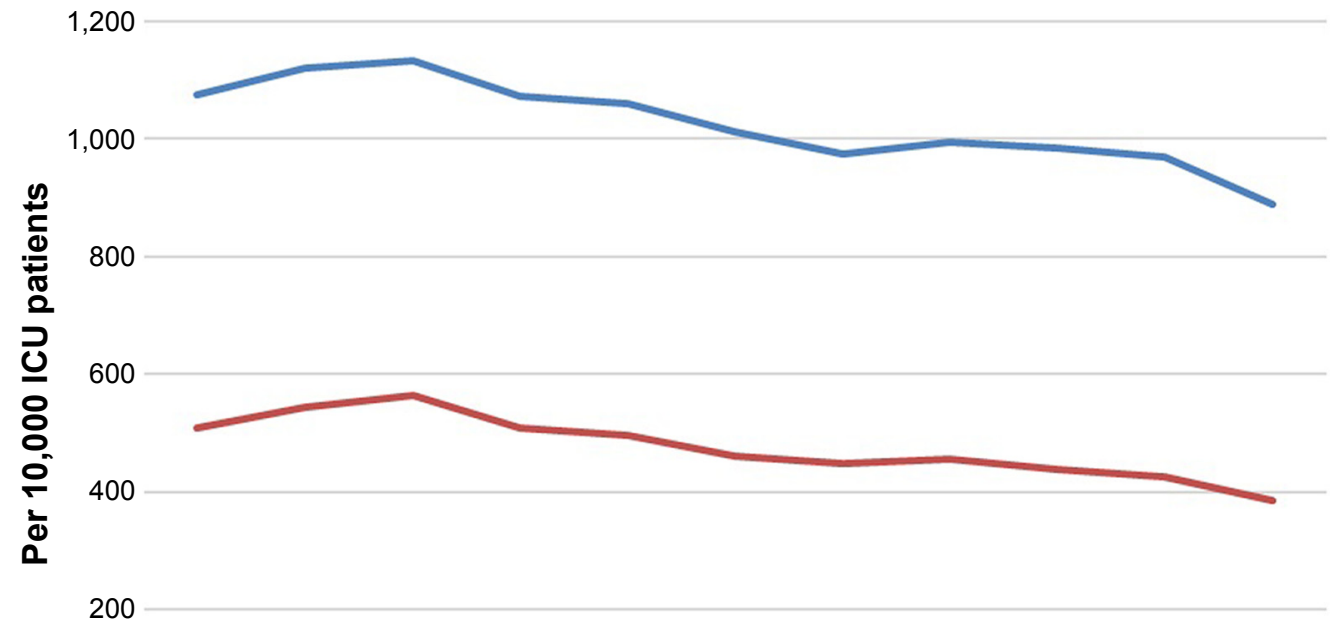

\begin{tabular}{|c|c|c|c|c|c|c|c|c|c|c|c|}
\hline & 2003 & 2004 & 2005 & 2006 & 2007 & 2008 & 2009 & 2010 & 2011 & 2012 & 2013 \\
\hline & $1,075.1$ & $1,120.9$ & $1,132.7$ & $1,071.7$ & $1,061.2$ & $1,012.8$ & 974.3 & 994.8 & 983.6 & 968.6 & 882.2 \\
\hline Female & 508.3 & 543.6 & 564.6 & 509.3 & 496.9 & 460.5 & 448.6 & 456.4 & 438.6 & 425.5 & 384 \\
\hline
\end{tabular}

Figure 2 Trends in COPD patients per 10,000 ICU patients by gender. 
ventilation and ICU care. Our data showed a similar trend for COPD patients with cancer admitted to the ICU, which increased in this study period; whether these patients were in terminal stages would require further investigation.

The COPD patients per 10,000 ICU patients gradually decreased in both genders. After age stratification, the proportion of patients older than 70 years declined more than those of the other age groups. Cheng et $\mathrm{al}^{10}$ showed that the mean age increased in ICU patients from 64.5 years in 2004 to 65.6 years in 2009. In our study, the percentage of COPD patients older than 60 years admitted to the ICU decreased, while the number of total ICU patients with COPD increased.

Our study has some limitations. This study was generally based on claims data and physician-generated diagnoses; therefore, miscoding and over or under coding might exist. Furthermore, our database lacked information on laboratory data, pulmonary function tests, COPD severity, and Acute Physiology and Chronic Health Evaluation II scores. However, the yearly trends found in this study should be fully reliable, because the sample was sufficiently large to minimize bias and reveal a significant nationwide trend. We used descriptive studies to describe characteristics of a COPD population and monitor trends of all-cause ICU admission. It did not answer questions about why the characteristics occurred and did not have a comparison group to allow conclusions about increasing ICU due to natural upward trend.

\section{Conclusion}

During the 11-year study period, the number of COPD patients in the ICU, length of ICU stays, and in-hospital mortality increased. The comorbidities of COPD patients in the ICU including diabetes, hypertension, and coronary artery disease also increased. Understanding the trends in COPD patients in the ICU is important for appropriate health care planning and the allocation of medical resources. Furthermore, a national-level study may detect patterns across different populations and geographic regions, which may aid the recognition of disease characteristics specific to certain locations or groups to facilitate the design of more efficient interventional strategies.

\section{Disclosure}

The authors report no conflicts of interest in this work.

\section{References}

1. Lozano R, Naghavi M, Foreman K, et al. Global and regional mortality from 235 causes of death for 20 age groups in 1990 and 2010: a systematic analysis for the Global Burden of Disease Study 2010. Lancet. 2012;380(9859):2095-2128.

2. Mannino DM, Homa DM, Akinbami LJ, Ford ES, Redd SC. Chronic obstructive pulmonary disease surveillance-United States, 1971-2000. MMWR Surveill Summ. 2002;51(6):1-16.

3. Fuhrman C, Roche N, Vergnenègre A, Zureik M, Chouaid C, Delmas MC. Hospital admissions related to acute exacerbations of chronic obstructive pulmonary disease in France, 1998-2007. Respir Med. 2011;105(4): 595-601.

4. de Miguel-Díez J, Jiménez-García R, Hernández-Barrera V, et al. Trends in hospital admissions for acute exacerbation of COPD in Spain from 2006 to 2010. Respir Med. 2013;107(5):717-723.

5. Molinari N, Briand C, Vachier I, et al. Hospitalizations for COPD exacerbations: trends and determinants of death. COPD. 2015;12(6): 621-627.

6. Lange P, Marott JL, Vestbo J, et al. Prediction of the clinical course of chronic obstructive pulmonary disease, using the new GOLD classification: a study of the general population. Am J Respir Crit Care Med. 2012;186:975-981.

7. Mannino DM, Homa DM, Akinbami LJ, et al. Chronic obstructive pulmonary disease surveillance-United States, 1971-2000. MMWR Surveill Summ. 2002;51:1-16.

8. Benseñor IM, Fernandes TG, Lotufo PA. Chronic obstructive pulmonary disease in Brazil: mortality and hospitalization trends and rates, 1996-2008. Int J Tuberc Lung Dis. 2011;15(3):399-404.

9. The World Bank [webpage on the Internet]. Available from: https://data. worldbank.org/indicator/SP.POP.65UP.TO.ZS?locations=JP\&year_ high_desc=true. Accessed December 1, 2017.

10. Cheng KC, Lu CL, Chung YC, et al. ICU service in Taiwan. J Intensive Care. 2014;2(1):8.

11. Ho CH, Chen YC, Wang JJ, Liao KM. Incidence and relative risk for developing cancer among patients with COPD: a nationwide cohort study in Taiwan. BMJ Open. 2017;7(3):e013195.

12. Langton JM, Blanch B, Drew AK, Haas M, Ingham JM, Pearson SA. Retrospective studies of end-of-life resource utilization and costs in cancer care using health administrative data: a systematic review. Palliat Med. 2014;28(10):1167-1196.

13. Tang ST, Wu SC, Hung YN, Huang EW, Chen JS, Liu TW. Trends in quality of end-of-life care for Taiwanese cancer patients who died in 2000-2006. Ann Oncol. 2009;20(2):343-348.

14. Tang ST, Chen ML, Huang EW, Koong SL, Lin GL, Hsiao SC. Hospice utilization in Taiwan by cancer patients who died between 2000 and 2004. J Pain Symptom Manage. 2007;33(4):446-453.
International Journal of COPD

\section{Publish your work in this journal}

The International Journal of COPD is an international, peer-reviewed journal of therapeutics and pharmacology focusing on concise rapid reporting of clinical studies and reviews in COPD. Special focus is given to the pathophysiological processes underlying the disease, intervention programs, patient focused education, and self management protocols.

\section{Dovepress}

This journal is indexed on PubMed Central, MedLine and CAS. The manuscript management system is completely online and includes a very quick and fair peer-review system, which is all easy to use. Visit $\mathrm{http} / / / \mathrm{www}$.dovepress.com/testimonials.php to read real quotes from published authors. 